\title{
Green synthesis of copper oxide nanoparticles using gum karaya as a biotemplate and their antibacterial application
}

This article was published in the following Dove Press journal:

International Journal of Nanomedicine

27 February 2013

Number of times this article has been viewed

\section{Vinod Vellora Thekkae Padil Miroslav Černík \\ Laboratory of Chemical Remediation Processes, Institute for Nanomaterials, Advanced Technology and Innovation, Technical University of Liberec, Studentská 1402/2, Liberec, Czech Republic}

Background: Copper oxide $(\mathrm{CuO})$ nanoparticles have attracted huge attention due to catalytic, electric, optical, photonic, textile, nanofluid, and antibacterial activity depending on the size, shape, and neighboring medium. In the present paper, we synthesized $\mathrm{CuO}$ nanoparticles using gum karaya, a natural nontoxic hydrocolloid, by green technology and explored its potential antibacterial application.

Methods: The $\mathrm{CuO}$ nanoparticles were synthesized by a colloid-thermal synthesis process. The mixture contained various concentrations of $\mathrm{CuCl}_{2} \cdot 2 \mathrm{H}_{2} \mathrm{O}(1 \mathrm{mM}, 2 \mathrm{mM}$, and $3 \mathrm{mM})$ and gum karaya $(10 \mathrm{mg} / \mathrm{mL})$ and was kept at $75^{\circ} \mathrm{C}$ at $250 \mathrm{rpm}$ for 1 hour in an orbital shaker. The synthesized $\mathrm{CuO}$ was purified and dried to obtain different sizes of the $\mathrm{CuO}$ nanoparticles. The well diffusion method was used to study the antibacterial activity of the synthesized $\mathrm{CuO}$ nanoparticles. The zone of inhibition, minimum inhibitory concentration, and minimum bactericidal concentration were determined by the broth microdilution method recommended by the Clinical and Laboratory Standards Institute.

Results: Scanning electron microscopy analysis showed $\mathrm{CuO}$ nanoparticles evenly distributed on the surface of the gum matrix. X-ray diffraction of the synthesized nanoparticles indicates the formation of single-phase $\mathrm{CuO}$ with a monoclinic structure. The Fourier transform infrared spectroscopy peak at $525 \mathrm{~cm}^{-1}$ should be a stretching of $\mathrm{CuO}$, which matches up to the $\mathrm{B}_{2 \mathrm{u}}$ mode. The peaks at $525 \mathrm{~cm}^{-1}$ and $580 \mathrm{~cm}^{-1}$ indicated the formation of $\mathrm{CuO}$ nanostructure. Transmission electron microscope analyses revealed $\mathrm{CuO}$ nanoparticles of $4.8 \pm 1.6 \mathrm{~nm}, 5.5 \pm 2.5 \mathrm{~nm}$, and $7.8 \pm 2.3 \mathrm{~nm}$ sizes were synthesized with various concentrations of $\mathrm{CuCl}_{2} \cdot 2 \mathrm{H}_{2} \mathrm{O}(1 \mathrm{mM}, 2 \mathrm{mM}$, and $3 \mathrm{mM}$ ). X-ray photoelectron spectroscopy profiles indicated that the $\mathrm{O} 1 \mathrm{~s}$ and $\mathrm{Cu} 2 \mathrm{p}$ peak corresponding to the $\mathrm{CuO}$ nanoparticles were observed. The antibacterial activity of the synthesized nanoparticles was tested against Gram-negative and positive cultures.

Conclusion: The formed $\mathrm{CuO}$ nanoparticles are small in size $(4.8 \pm 1.6 \mathrm{~nm})$, highly stable, and have significant antibacterial action on both the Gram classes of bacteria compared to larger sizes of synthesized $\mathrm{CuO}(7.8 \pm 2.3 \mathrm{~nm})$ nanoparticles. The smaller size of the $\mathrm{CuO}$ nanoparticles $(4.8 \pm 1.6 \mathrm{~nm})$ was found to be yielding a maximum zone of inhibition compared to the larger size of synthesized $\mathrm{CuO}$ nanoparticles $(7.8 \pm 2.3 \mathrm{~nm})$. The results also indicate that increase in precursor concentration enhances an increase in particle size, as well as the morphology of synthesized $\mathrm{CuO}$ nanoparticles.

Keywords: gum karaya, $\mathrm{CuO}$ nanoparticles, XRD, FTIR, XPS, antibacterial activity

Processes, Institute for Nanomaterials,

Advanced Technology and Innovation

(CXI), Technical University of Liberec,

Studentská 1402/2, Liberec I, 46I I7,

Czech Republic

Tel +420485353017

Fax +420485353445

Email miroslav.cernik@tul.cz

\section{Introduction}

Copper oxide $(\mathrm{CuO})$ nanoparticles are important due to their applications as antimicrobials and in gas sensors, batteries, high temperature superconductors, solar energy conversion tools, and so on. ${ }^{1-4}$ Human beings have been using copper $(\mathrm{Cu})$ and $\mathrm{Cu}$ 
complexes for various purposes for centuries, such as water purifiers, algaecides, fungicides, and as antibacterial and antifouling agents. ${ }^{5}$ Natural plant materials such as magnolia leaf extract and stem latex of Euphorbia nivulia have been used for the synthesis of $\mathrm{Cu}$ nanoparticles. The application of these nanoparticles expresses superior antibacterial activity against Escherichia coli cells. The nanoparticles have also been used as nontoxic aqueous formulations for administration of cancer therapy. ${ }^{6-7} \mathrm{Cu}$ and $\mathrm{CuO}$ nanoparticles have been studied as potential antimicrobial agents against infectious organisms such as E. coli, Bacillus subtilis, Vibria cholera, Pseudomonas aeruginosa, Syphillis typhus, and Staphylococcus aureus. ${ }^{8-10}$ Kattumuri et al ${ }^{11}$ explored the possibility of utilizing gum arabic as a nontoxic, natural hydrocolloid used in the production of readily administrable biocompatible gold nanoparticles for diagnostic and therapeutic applications. They have also demonstrated that complex polysaccharides and protein structures within the gum arabic backbone can effectively lock gold nanoparticles to produce nontoxic, nanoparticulate constructs that are stable under in vivo conditions for potential applications in nanomedicine. Thus, this investigation elucidates that natural gums could act as nontoxic vehicles to stabilize and deliver nanoparticles for in vivo applications.

The preparation of $\mathrm{CuO}$ nanoparticles uses a variety of methods including sol-gel, quick precipitation, sonochemical, electrochemical, solid state reaction, alcohothermal synthesis, microwave irradiation, and liquid-liquid interface techniques involving organic solvents and harsh reducing agents. ${ }^{12-20}$ Therefore, it was a challenge to find a convenient, mild, nontoxic, natural product to produce metal nanoparticles in an aqueous environment. Amongst various natural materials used for nanoparticle construction, plants seem to be the best candidates, and nanoparticles produced by plants are more stable, are of various sizes and shapes, and the rate of production is faster than in the case of microorganisms. ${ }^{21}$ Biosynthesis of metal/metal oxide nanoparticles using environmentally friendly methods without the use of harsh, toxic reducing agents (eg, hydrazine hydrate, sodium borohydride, dimethylformamide, ethylene glycol, and so on), and expensive chemicals are the main principle of green chemistry. Many of these reducing agents have been associated with environmental toxicity or biological hazards. With an increasing interest in the minimization or total elimination of waste and the execution of sustainable processes through the implementation of the fundamental principles of green chemistry, the development of natural and biomimetic approaches for the preparation of nanomaterials is a desirable aspect. ${ }^{22,23}$ Hence, there is a need to develop newer ecofriendly processes for the synthesis of metal/metal oxide nanoparticles of controlled shapes and sizes, and such methods could permit the nanoparticles to be extensively used in biological systems.

Polysaccharide hydrocolloids such as carrageenan, alginate, agar-agar, starches, pectin, guar and gums (arabic, tragacanth, and karaya) are high molecular weight macromolecules. Gums are naturally occurring polysaccharide components in plants, which are fundamentally economical and easily available. They have assorted applications as thickeners, food emulsifiers, viscosifiers, sweeteners, and so on in confectionery, and as binders and drug release modifiers in pharmaceutical dosage forms. ${ }^{24}$ Traditionally, India is the largest producer and exporter of gum karaya (GK), while Europe is the largest importer of GK.$^{25}$ Physicochemical properties, as well as the structural, occurrence, production, food, and nonfood applications of GK have been widely studied by different research groups. ${ }^{26-28} \mathrm{GK}$ is a partially acetylated polysaccharide and has a branched structure and high molecular mass of $\sim 16.0 \times 10^{9} \mathrm{Da}$, and is grouped under substituted rhamnogalacturonoglycan (pectic) type tree gums. This gum contains about $60 \%$ neutral sugars (rhamnose and galactose) and $40 \%$ acidic sugars (glucuronic acid and galacturonic acids). ${ }^{29}$ The toxicological evaluation of GK had established that this gum was nontoxic and has potential application as a food additive. ${ }^{30}$

Biosynthesis of metal nanoparticles by plants is currently under development. The synthesis of metal nanoparticles using inactivated plant tissue, plant extracts, exudates, and other parts of living plants is a modern alternative for their production. ${ }^{31}$ It is a very cost effective method and therefore a prospective commercial alternative for large-scale production.

Natural hydrocolloids isolated from trees are a new class of potentially economical and environmentally compassionate biomaterial that exhibit a high specificity for the production of nanomaterials. Gums from plants may act both as reducing and capping agents in nanoparticle synthesis. The bioreduction of metal nanoparticles by a combination of biomolecules found in plant extracts (eg, enzymes, proteins, amino acids, vitamins, polysaccharides, and organic acids such as citrates) is environmentally benign, yet chemically complex. Because of the important and critical roles of plants in bio-based protocols for metal nanoparticle production, the green synthesis of metal nanoparticles using GK is an important subject in this paper. Further, this study aims to explore the proficiency of these nanoparticles as antibacterial agents against human pathogenic bacteria, mainly $E$. coli and $S$. aureus.

As part of our ongoing research work on the design and development of nanoparticulate constructs using natural tree 
gums, herein we report the development of a new class of composite material derived from a natural nontoxic GK biopolymer with $\mathrm{CuO}$ nanoparticles that are stable in vivo. The present work details a green chemistry approach to the synthesis of metal oxide nanoparticles using a well-characterized plant derived natural product GK, which acts as a reducing and templating agent. In this current research paper $\mathrm{CuO}$ nanoparticles have been synthesized and characterized by scanning electron microscope (SEM), transmission electron microscope (TEM), Fourier transform infrared spectroscopy (FTIR), X-ray diffraction (XRD), and X-ray photoelectron spectroscopy (XPS) analysis. Further, $\mathrm{CuO}$ nanoparticles were explored with respect to their prospective antibacterial application.

\section{Materials and methods Materials}

GK was obtained from the Sigma-Aldrich Company (SigmaAldrich, St Louis, MO, USA). The chemicals $\mathrm{CuCl}_{2} \cdot 2 \mathrm{H}_{2} \mathrm{O}$, $\mathrm{NaOH}$, and $\mathrm{HCl}$ were analytical grade and used as received without further purification.

\section{GK preparation}

GK powder ( $1 \mathrm{~g}$ ) was exactly weighed and dispensed into a clean glass beaker containing $1 \mathrm{~L}$ of deionized water. The procedures for the preparation of GK lyophilized powder was based on the earlier reported method used for other natural tree gums. ${ }^{32}$ The gum solution was gently stirred overnight at room temperature. Later, undissolved matter was separated by keeping the gum solution at room temperature $\left(25^{\circ} \mathrm{C}\right)$ for an additional 18 hours and filtered through a sintered glass funnel (\#G-2 followed by \#G-4). The obtained clear solution was freeze-dried and stored for further use.

\section{Preparation of $\mathrm{CuO}$ nanoparticles}

The $\mathrm{CuO}$ nanoparticles were synthesized by a colloidthermal synthesis process. ${ }^{15}$ In separate $50 \mathrm{~mL}$ conical flasks, $100 \mu \mathrm{L}$ aliquot of $10 \mathrm{mM}$ solutions of $\mathrm{CuCl}_{2} \cdot 2 \mathrm{H}_{2} \mathrm{O}$ was mixed with $10 \mathrm{~mL}$ of the GK solution prepared above (100 mg gum dispersed in $10 \mathrm{~mL}$ of deionized water) and $\mathrm{NaOH} \cdot \mathrm{CuCl}_{2} \cdot 2 \mathrm{H}_{2} \mathrm{O}$ and $\mathrm{NaOH}$ in a molar ratio of 2:5 were maintained in the mixture. All the solution components were purged with nitrogen prior to use and all chemical processes proceeded in the presence of nitrogen. The mixture containing $\mathrm{CuCl}_{2} \cdot 2 \mathrm{H}_{2} \mathrm{O}$ and $\mathrm{GK}$ was kept at $75^{\circ} \mathrm{C}$ at $250 \mathrm{rpm}$ for 1 hour in an orbital shaker. The color of the mixtures gradually changed from bluish to black, indicating the formation of $\mathrm{CuO}$ nanoparticles. The resulting precipitate was obtained by centrifugation and washed with ethanol and distilled water, respectively, and finally freeze-dried.

\section{Characterization of $\mathrm{CuO}$ nanoparticles SEM analysis}

Morphology of the nanoparticles was studied using SEM analysis (SEM-LEO S1430 VP from M/S LEO Electron Microscopy Ltd, Cambridge, UK and UHR FE-SEM Carl Zeiss ULTRA Plus, Carl Zeiss Meditec AG, Jena, Germany).

\section{X-ray diffraction analysis}

XRD patterns were obtained with $\mathrm{Cu}-\mathrm{K} \alpha$ radiation using a diffractometer (Philips PW 3710/3020, Netherlands) equipped with a graphite monochromator. The measurements were made using a step-scanning program with $0.02^{\circ}$ per step and an acquisition time of 5 seconds per step. The XRD data were analyzed using X'Pert High Score software (PANanlytical BV Almelo, Netherlands) for the identification of the crystalline phases.

\section{Fourier transform infrared spectroscopy analysis}

FTIR spectra were obtained using a spectrophotometer (Nicolet IZ10, Thermo Fisher Scientific, Waltham, MA, USA) in the spectral region of $4000-400 \mathrm{~cm}^{-1}$ using a resolution of $4 \mathrm{~cm}^{-1}$ and 64 coadded scans. All the colloidal nanoparticles were freeze-dried in the form of nanopowders and palletized with $\mathrm{KBr}$ for FTIR studies.

\section{Transmission electron microscopy}

TEM images for these nanoparticles were recorded using a TEM operating at an acceleration voltage of $15 \mathrm{kV}$ (Tecnai F12; North American NanoPort, Hillsboro, OR, USA). For TEM measurements, samples were prepared by dropping 10-20 $\mu \mathrm{L}$ of $\mathrm{CuO}$ nanoparticle dispersions on a $\mathrm{Cu}$ grid and subsequently dried at room temperature.

\section{X-ray photoelectron spectroscopy analysis}

XPS analysis of $\mathrm{CuO}$ and $\mathrm{GK}$ powder samples was performed (Kratos XPS system, AXIS HIS-165 Ultra; Shimadzu Corporation, Kyoto, Japan) to confirm the $\mathrm{CuO}$ and $\mathrm{GK}$ composition. Survey scans were recorded in the binding energy range of 0 to 1100 electron volts $(\mathrm{eV})$ with pass energy of $80 \mathrm{eV}$. When comparing the results with the reference, peaks were identified as being the same if the difference of the peak position was within $0.5 \mathrm{eV}$.

\section{Antimicrobial tests}

\section{Bacterial strains}

E. coli MTCC 443 and $S$. aureus MTCC 737 were used as reference strains for Gram-negative and Gram-positive bacteria, respectively, following guidelines of the Clinical and Laboratory Standards Institute. ${ }^{33}$ Strains were grown on nutrient agar. 


\section{Agar well diffusion method}

The well diffusion method was used to study the antibacterial activity of the synthesized $\mathrm{CuO}$ nanoparticles. All the glassware, media, and reagents used were sterilized in an autoclave at $121^{\circ} \mathrm{C}$ for 20 minutes. The bacterial suspension was prepared by growing a single colony overnight in nutrient broth and by adjusting the turbidity to $0.5 \mathrm{McFarland}$ standards. Mueller Hinton agar plates were inoculated with this bacterial suspension, and $50 \mu \mathrm{g}(100 \mu \mathrm{L})$ of $\mathrm{CuO}$ nanoparticles were added to the center well with a diameter of $8 \mathrm{~mm}$. The nanoparticles used here were prepared with $10 \mathrm{mg} / \mathrm{mL}$ of GK solution containing $1 \mathrm{mM}, 2 \mathrm{mM}$, and $3 \mathrm{mM}$ of $\mathrm{CuCl}_{2} \cdot 2 \mathrm{H}_{2} \mathrm{O}$ autoclaved for 60 minutes. Control plates were maintained with autoclaved GK loaded wells. Antibiotic such as tetracycline was used as a positive control. These plates were incubated at $37^{\circ} \mathrm{C}$ for 24 hours in a bacteriological incubator, and the zone of inhibition (ZOI) was measured by subtracting the well diameter from the total inhibition zone diameter. All tests were performed three times.

\section{Determination of minimal inhibitory/bactericidal concentrations}

Minimum inhibitory concentrations (MIC) and minimum bactericidal concentrations ( $\mathrm{MBC}$ ) of the $\mathrm{CuO}$ nanoparticles were determined by the broth microdilution method recommended by the Clinical and Laboratory Standards Institute in $2000 .{ }^{33}$ Tetracycline was used as a positive control. The suspension of GK $(10 \mathrm{mg} / \mathrm{mL})$ was used as negative control in all experiments. A dilution series with $5 \mathrm{~mL}$ of nutrient broth medium containing $10-100 \mu \mathrm{g} / \mathrm{mL}$ of $\mathrm{CuO}$ nanoparticles was prepared. For the MIC determination, the suspensions were prepared by suspending one isolate colony from nutrient plates in $50 \mu \mathrm{L}$ of nutrient broth. After 24 hours of growth, suspensions were diluted in distilled water to obtain final inoculums of $5 \times 10^{5}-5 \times 10^{6}$ colony-forming units/ $\mathrm{mL}$. The purity of isolates was checked throughout the study by examining the colony morphology and Gram staining. Two-fold serial dilutions of $\mathrm{CuO}$ nanoparticle solutions were prepared in nutrient broth in 98-well plates starting from a stock solution of $10^{-2} \mathrm{M}$. An equal volume of bacterial inoculums was added to each well on the microtiter plate containing $0.05 \mathrm{~mL}$ of the serial compound dilutions. After incubation for $18-24$ hours at $35^{\circ} \mathrm{C}$, MIC was determined with an enzyme-linked immunosorbent assay reader (Infinite 200; Tecan Systems, Inc, San Jose, CA, USA) as the lowest concentration of compound whose absorbance was comparable with the negative control wells (broth only or broth with $\mathrm{CuO}$ nanoparticles, without inoculums). Results are expressed as the mean values of three independent determinations.

\section{Statistical analysis}

Each experiment was repeated three times, and the resulting bacterial growths on three plates corresponding to a particular sample were reported as the mean \pm standard deviation $(n=3)$. The MIC and MBC experimental analysis was based on three independent sample analyses.

\section{Results and discussion Morphology of GK and $\mathrm{CuO}$ nanoparticles by SEM analysis}

The morphology of GK before and after the deposition of $\mathrm{CuO}$ nanoparticles studied by SEM is presented in Figure 1. The morphology of GK indicates irregular particles of various sizes (Figure 1A), whereas the lyophilized sample is appearing as crumbled-like structure (Figure 1B). The $\mathrm{CuO}$ nanoparticles appear as small needle-like structures on the surface of the gum matrix (Figure 1C). The SEM micrographs were obtained after washing the dried GK$\mathrm{CuO}$ thrice with deionized water. One can notice that no metal oxide nanoparticles are seen outside the gum matrix, which can be attributed to the strong locking of nanoparticles within the gum matrix. This clearly suggests that the $\mathrm{CuO}$ nanoparticles are bound to the surface of the gum matrix.

\section{XRD analysis}

The XRD pattern of GK and $\mathrm{CuO}$ nanoparticles is depicted in Figure 2. As shown in Figure 2A, the XRD pattern of $\mathrm{GK}$ is amorphous in nature whereas the $\mathrm{CuO}$ nanoparticles (Figure 2B) demonstrate that the $\mathrm{CuO}$ is crystalline in nature. The spectrum is identical to that of pure $\mathrm{CuO}$, indicating the formation of single-phase $\mathrm{CuO}$ with monoclinic structure (JCPDS-05-0661). ${ }^{34}$ In the present work, the diffraction patterns were observed to be at $2 \theta=32.47,35.49,38.68,48.65$, $53.36,58.25$ and 61.45 were assigned to the reflection lines of monoclinic $\mathrm{CuO}$ nanoparticles. The present experimental results were found to be in agreement with the reported diffraction patterns of $\mathrm{CuO}$ nanoparticles prepared by Das et al. ${ }^{35}$

\section{FTIR analysis}

The FTIR spectra of GK and $\mathrm{CuO}$ nanoparticles are shown in Figure 3. The main characteristic peaks of GK at $1047 \mathrm{~cm}^{-1}$ and $1422 \mathrm{~cm}^{-1}(\mathrm{C}-\mathrm{O}$ stretch$), 1630 \mathrm{~cm}^{-1}(\mathrm{C}=\mathrm{O}$ stretch and $\mathrm{N}-\mathrm{H}$ bending), $1734 \mathrm{~cm}^{-1}$ ( $\mathrm{CH}_{3} \mathrm{CO}$ group), $2990 \mathrm{~cm}^{-1}$ (C-H stretch), and 3000-3600 $\mathrm{cm}^{-1}(\mathrm{O}-\mathrm{H}$ stretch) were 

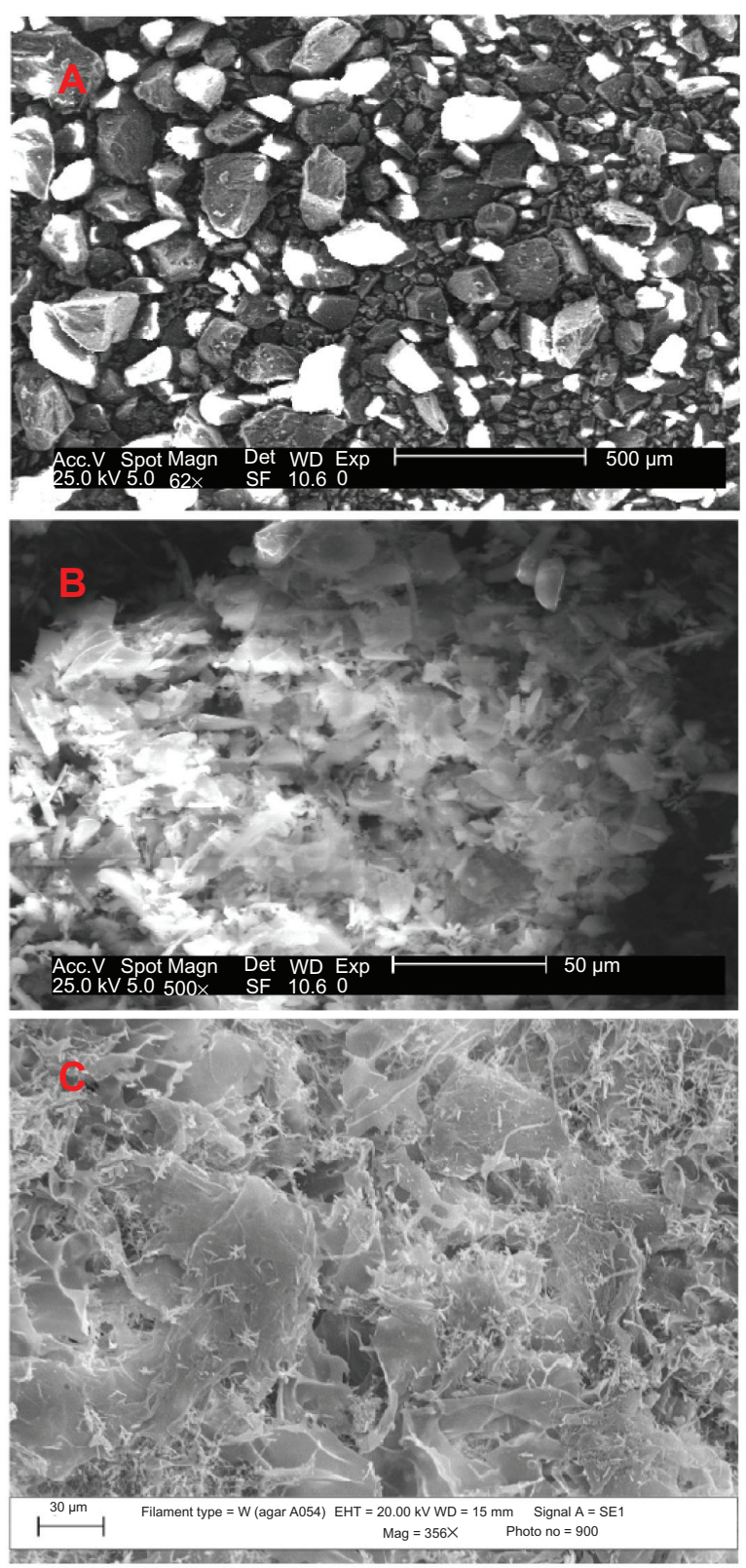

Figure I Typical SEM photo micrographs of (A) GK powder, (B) lyophilized GK, and $(\mathbf{C})$ synthesized $\mathrm{CuO}$ nanoparticles.

Abbreviations: SEM, scanning electron microscopy; GK, gum karaya; CuO, copper oxide.

observed. The FTIR spectrum of a $\mathrm{CuO}$ nanoparticle shows broad absorption bands between 2800 and $4000 \mathrm{~cm}^{-1}$ mainly ascribed to $\mathrm{OH}^{-}$and $\mathrm{C}-\mathrm{O}$ groups on the surface of the $\mathrm{CuO}$ crystals nanostructure. The three infrared absorption peaks reveal the vibrational modes of $\mathrm{CuO}$ nanostructures in the range of 500-700 $\mathrm{cm}^{-1}$. The major peaks were observed to be $525 \mathrm{~cm}^{-1}, 580 \mathrm{~cm}^{-1}$ and $675 \mathrm{~cm}^{-1}$, respectively (Figure 3). The peak at $525 \mathrm{~cm}^{-1}$ should be a stretching of $\mathrm{Cu}-\mathrm{O}$, which matches up to the $\mathrm{B}_{2 \mathrm{u}}$ mode. ${ }^{36}$ This peak corroborates the XRD analysis where the corresponding plane (202) represents the
A
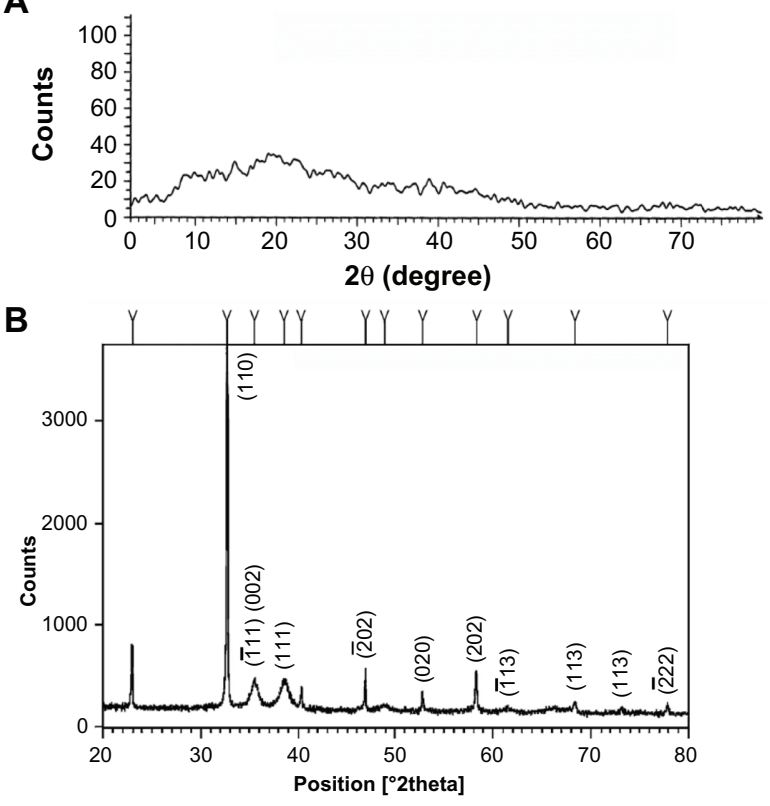

Figure 2 XRD pattern of synthesized CuO nanoparticles. XRD pattern of (A) GK and (B) $\mathrm{CuO}$ nanoparticles, indicating the amorphous nature of GK and the crystalline nature with different planes of synthesized $\mathrm{CuO}$ nanoparticles.

Abbreviations: XRD, X-ray diffraction; GK, gum karaya; $\mathrm{CuO}$, copper oxide.

$\mathrm{Cu}-\mathrm{O}$ stretching mode. The peaks at $525 \mathrm{~cm}^{-1}$ and $580 \mathrm{~cm}^{-1}$ indicated the formation of the $\mathrm{CuO}$ nanostructure.

\section{TEM analysis}

The $\mathrm{CuO}$ nanoparticles synthesized by the present method are smaller in size and show minimum agglomeration. Figure 4 shows the TEM images of $\mathrm{CuO}$ nanoparticles synthesized by treating $1 \mathrm{mM}, 2 \mathrm{mM}$, and $3 \mathrm{mM} \mathrm{CuCl}_{2} \cdot 2 \mathrm{H}_{2} \mathrm{O}$ with a metal ion concentration of $10 \mathrm{mg} / \mathrm{mL}$ of aqueous $\mathrm{GK}$.

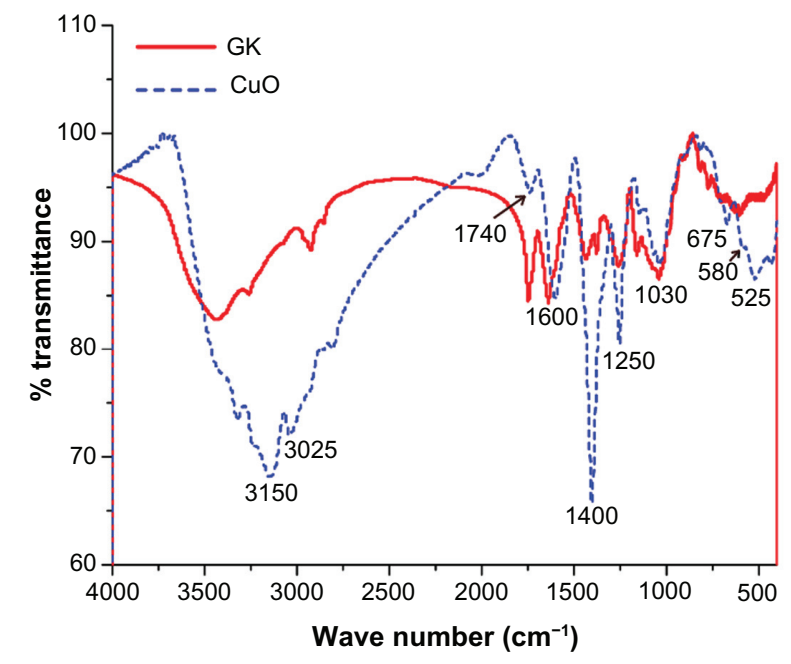

Figure 3 FTIR analysis of GK and $\mathrm{CuO}$ nanoparticles indicating the involvement of various functional groups in the formation of metal oxide nanoparticles.

Abbreviations: FTIR, Fourier transform infrared spectroscopy; GK, gum karaya; $\mathrm{CuO}$, copper oxide. 
As can be seen in all the images, the gum networks are clearly embedded with well separated, spherical nanoparticles with diameters ranging from $2 \mathrm{~nm}$ to $10 \mathrm{~nm}$. In the case of the $1 \mathrm{mM}$ concentration of $\mathrm{CuCl}_{2} \cdot 2 \mathrm{H}_{2} \mathrm{O}$ used, monodispersed nanoparticles $(7.8 \pm 2.3 \mathrm{~nm})$ were observed (Figure 4A), while in the case of higher concentrations of $\mathrm{CuCl}_{2} \cdot 2 \mathrm{H}_{2} \mathrm{O}$ ( $2 \mathrm{mM}$ and $3 \mathrm{mM}$ ), the formed $\mathrm{CuO}$ particles size varied from $5.5 \pm 2.5 \mathrm{~nm}$ to $4.8 \pm 1.6 \mathrm{~nm}$ (Figure $4 \mathrm{~B}$ and C), respectively. In all cases, some kind of regular distribution of nanoparticles in the form of self-assembled arrays within the gum matrix could be noticed. The representative selected area electron (SAED) pattern for $\mathrm{CuO}$ nanoparticles obtained with the gum extract is shown in Figure 4. SAED patterns show various diffraction rings of monoclinic $\mathrm{CuO}$ (Figure 4A-C). The experiments were conducted in order to study the capping nature of GK extract over the growth and formation of nanoparticles by varying the metal precursor concentration with a fixed amount of GK $(10 \mathrm{mg} / \mathrm{mL})$. A comparison of the morphologies indicates that with an increase in the concentration of the metal precursor, the resulting $\mathrm{CuO}$ nanoparticles contain a greater number of particles with distinctive changes in particle sizes (Figure 4A-C). Further, on increasing the concentration of $\mathrm{CuO}$, a mass of separated $\mathrm{CuO}$ nanoparticles of controlled sizes was observed, and this can be attributed to the ability of the gum matrix to regulate the sizes of the nanoparticles.

The exact mechanism leading to the intracellular formation of $\mathrm{CuO}$ nanoparticles by challenging the gum product with the corresponding metal ions is not fully understood. We speculate that since the nanoparticles are formed on
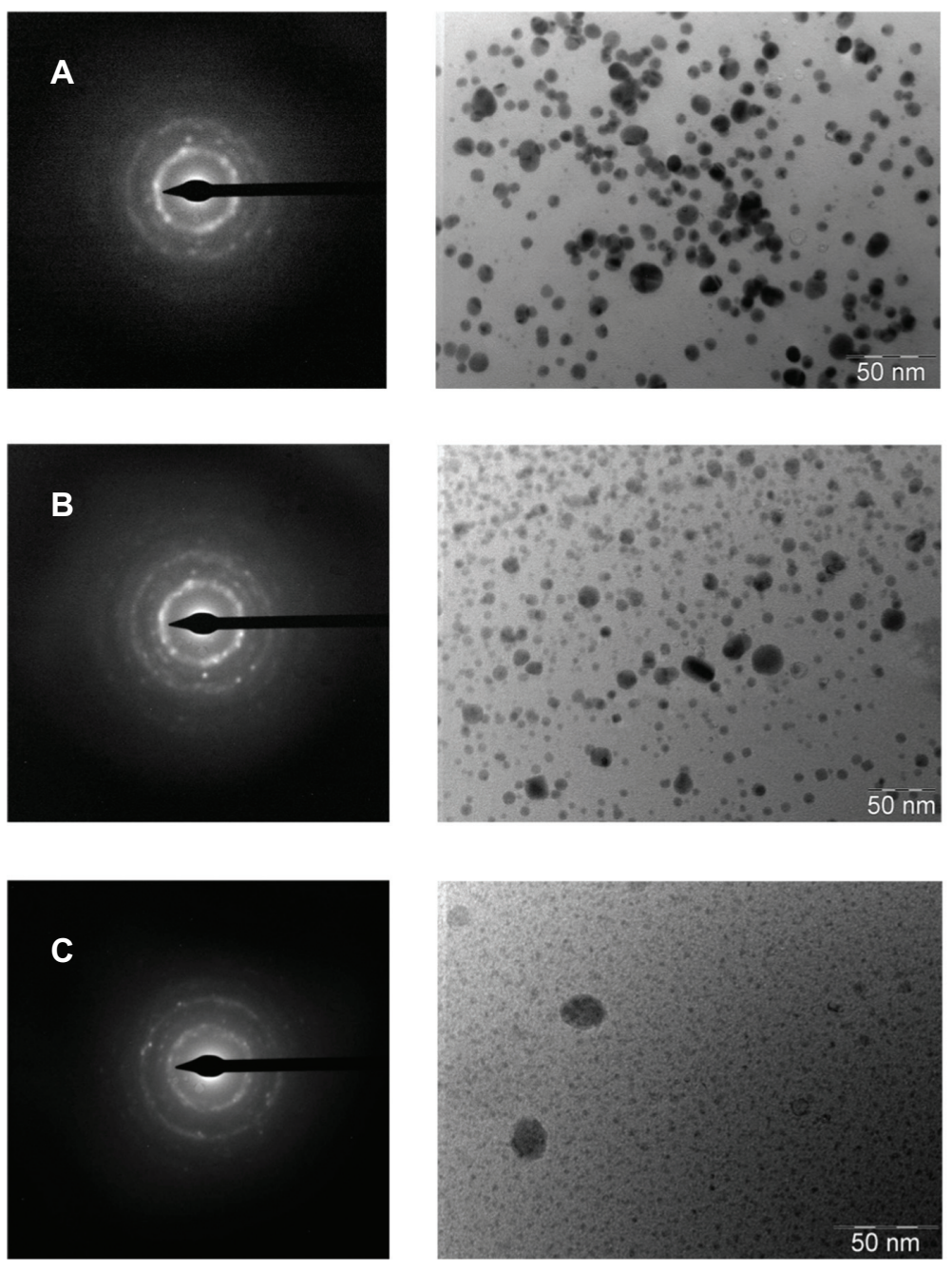
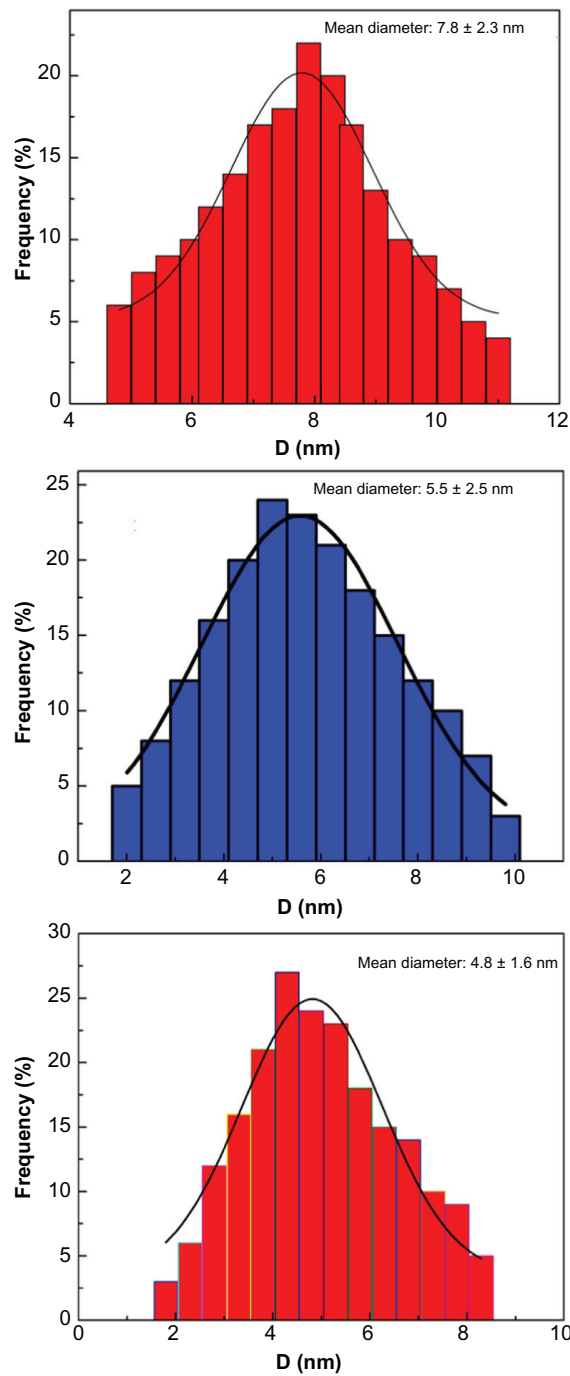

Figure 4 TEM photo micrographs showing synthesized $\mathrm{CuO}$ nanoparticles of various sizes with corresponding SAED patterns and histograms of particle size distribution of $\mathrm{CuO}$ nanoparticles synthesized at various concentrations of metal precursor. In the histograms, the sizes of major nanoparticles are reported as mean \pm standard deviation. Mean particle size distribution for (A) $7.8 \pm 2.3 \mathrm{~nm}$; (B) $5.5 \pm 2.5 \mathrm{~nm}$; and (C) $4.8 \pm 1.6 \mathrm{~nm}$, respectively.

Abbreviations: TEM, transmission electron microscopy; CuO, copper oxide; SAED, selected area electron diffraction; D, diameter. 
the surface of the gum and not in the solution, the first step involves a trapping of metal ions on the surface of the gum network possibly via an electrostatic interaction between the metal ions and the negatively-charged carboxylate and hydroxyl groups present in the biopolymer. ${ }^{25}$ The presence of various sugars, amino acids and fatty acids present in the GK could act as a reducing and capping agent for the formation of metal oxide nanoparticles. ${ }^{28}$ Upon hydrolysis, metal ions may lead to the formation of metal nuclei, and they subsequently grow and accumulate in the form of nanoparticles within the gum matrix. These assumptions can be validated by FTIR and XRD results.

\section{XPS analysis}

The XPS spectra of GK and $\mathrm{CuO}$ nanoparticles are presented in Figure 5A and B, respectively. As can be seen from the spectra, the XPS survey scans of pure GK show binding energy peaks characteristic of carbon and oxygen only. The observed $\mathrm{C} 1 \mathrm{~s}$ binding energy peaks assigned to $\mathrm{C}-\mathrm{C}, \mathrm{C}-\mathrm{O}$, and $\mathrm{C}=\mathrm{O}$ functional groups present in $\mathrm{GK}$ are in agreement with the observations made by FTIR. The $\mathrm{C}-\mathrm{O}$ and $\mathrm{C}=\mathrm{O}$ peaks can be associated with hydroxyl and carboxylate groups present in the biopolymer. The $\mathrm{O} 1 \mathrm{~s}$ high resolution narrow scans could be deconvoluted into binding energy peaks at $531.8 \mathrm{eV}$ and $532.7 \mathrm{eV}$, which can be dedicated to the $\mathrm{O}$ in the $\mathrm{C}=\mathrm{O}$ and alcoholic $\mathrm{C}-\mathrm{O}$ groups. The $\mathrm{C}=\mathrm{O}$ group may be seen due to the carboxylate groups present in the GK. The $\mathrm{Cu} 2 \mathrm{p}$ core level spectrum (Figure 5B) represents two peaks located at 933.4 and $953.8 \mathrm{eV}$, which corresponds to the $\mathrm{Cu}$ 2p3/2 and $\mathrm{Cu} 2 \mathrm{p} 1 / 2$, respectively. These values match well with the data reported for the $\mathrm{Cu}(2 \mathrm{p})$ in $\mathrm{CuO} .{ }^{16} \mathrm{The} \mathrm{Cu} 2 \mathrm{P}_{3 / 2}$ spectrum (inset Figure 5B) shows that the $\mathrm{Cu}^{2+}$ peak lies at $933.4 \mathrm{eV}$, with two shake-up satellites 7.2 and $9.8 \mathrm{eV}$ higher in binding energy than that of the main peak. As shown in Figure $5 \mathrm{~B}$, the $\mathrm{O} 1 \mathrm{~s}$ core-level spectrum is broad, and two $\mathrm{O} 1 \mathrm{~s}$ peaks, at a lower energy of $529.5 \mathrm{eV}$, is in agreement with $\mathrm{O}^{2-}$ in $\mathrm{CuO}$, while the other peak, at a higher energy of $531.6 \mathrm{eV}$, is attributed to $\mathrm{O}$ adsorbed on the surface of the $\mathrm{CuO}$ particles. ${ }^{37}$ Thus, the XPS results indicate that the nanoparticles are composed of $\mathrm{CuO}$. The strong shake-up satellites recorded in the $\mathrm{CuO}$ sample confirm the $\mathrm{Cu}^{2+}$ oxidation state, and rule out the possibility of the existence of a $\mathrm{Cu}_{2} \mathrm{O}$ phase..$^{15,16}$

\section{Antibactericidal tests}

The antibacterial activity of the $\mathrm{CuO}$ nanoparticle was tested against the Gram-negative bacteria E. coli and the Grampositive $S$. aureus. The results of the antibacterial activity
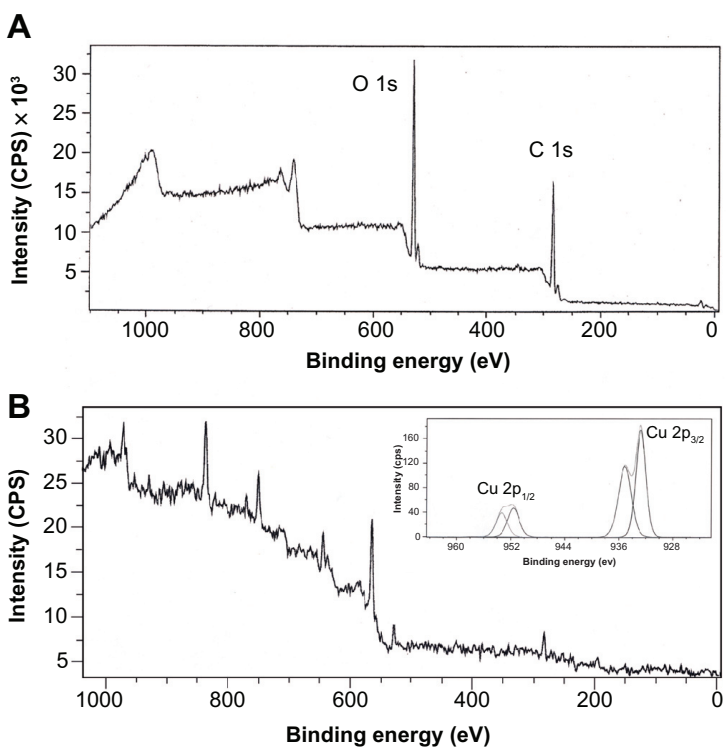

Figure 5 XPS survey scanning spectra of the (A) GK (B) GK-CuO nanoparticles formation.

Note: Inset figure $\mathrm{B}$ shows the spectra of the $\mathrm{CuO}$ nanoparticles formation. Abbreviations: XPS, X-ray photoelectron spectroscopy; GK, gum karaya; CuO, copper oxide; CPS, counts per second; eV, electron volts.

of $\mathrm{CuO}$ nanoparticles against these bacterium (ZOI, MIC, and $\mathrm{MBC}$ ) are presented in Table 1. The suspension of GK $(10 \mathrm{mg} / \mathrm{mL})$ as a negative control did not show any antibacterial activity. From the above-mentioned experiment it can be found that the $\mathrm{CuO}$ nanoparticles are effective in killing/ inhibiting a range of bacterial growth. The antibacterial activity of $\mathrm{CuO}$ nanoparticles against $E$. coli and $S$. aureus with ZOI are depicted in Figure 6. The ZOI of around $14.5 \pm 0.8 \mathrm{~mm}$ was observed for the Gram-positive bacteria strain S. aureus (American Type Culture Collection 25923), and in the case of the Gram-negative bacteria strain E. coli (American Type Culture Collection 25922), the detected ZOI was $16.2 \pm 0.8 \mathrm{~mm}$. Synthesized $\mathrm{CuO}$ with a size of $4.8 \pm 1.6 \mathrm{~nm}$ was used in both cases.

The other observation was that $\mathrm{CuO}$ nanoparticles synthesized at the range of $7.8 \pm 2.3 \mathrm{~nm}$ demonstrated a smaller ZOI than the smaller particles. The MIC of $\mathrm{CuO}$ nanoparticles was found to be $103.5 \pm 4.71 \mu \mathrm{g} / \mathrm{mL}$ for E. coli and $120.4 \pm 8.16 \mu \mathrm{g} / \mathrm{mL}$ for $S$. aureus, respectively (Table 1). Like MIC values, particle size dependent $\mathrm{CuO}$ $(4.8 \pm 1.6 \mathrm{~nm})$ synthesis had MBC values of $125 \pm 5.5 \mu \mathrm{g} / \mathrm{mL}$ for E. coli and $135 \pm 8.8 \mu \mathrm{g} / \mathrm{mL}$ for $S$. aureus (Table 1). The present experimental values are found to be slightly higher than the reported MIC for $\mathrm{CuO}$ nanoparticles synthesized by continuous gas phase production. ${ }^{38}$ Based on these results, it can be concluded that the synthesized $\mathrm{CuO}$ nanoparticles had significant antibacterial action on both 
Table I Antibacterial activity of $\mathrm{CuO}$ nanoparticles (ZOI, MIC, and MBC) as synthesized using GK extract against Escherichia coli and Staphylococcus aureus laboratory bacterial strains

\begin{tabular}{|c|c|c|c|c|c|c|}
\hline $\begin{array}{l}\text { Bacterial strains } \\
\text { used }\end{array}$ & ZOI (mm) & & $\begin{array}{l}\text { MIC } \\
(\mu \mathrm{g} / \mathrm{mL})\end{array}$ & $\begin{array}{l}\text { MBC } \\
(\mu \mathrm{g} / \mathrm{mL})\end{array}$ & $\begin{array}{l}\text { Control negative } \\
(10 \mathrm{mg} / \mathrm{mL})\end{array}$ & $\begin{array}{l}\text { Control positive } \\
\text { TC }(\mathrm{mm})\end{array}$ \\
\hline Escherichia coli & $16.2 \pm 0.8(\mathrm{~A})$ & $15.8 \pm 0.5(\mathrm{~B})$ & $103 \pm 4.7$ & $125 \pm 5.5$ & NA & $18 \pm 0.8$ \\
\hline Staphylococcus aureus & $14.5 \pm 0.6(C)$ & $13.8 \pm 0.4(D)$ & $120 \pm 8.1$ & $135 \pm 8.8$ & NA & $16 \pm 0.5$ \\
\hline
\end{tabular}

Notes: Values are expressed as mean \pm standard deviation $(n=3)$. CuO nanoparticles concentration used are $10-100 \mu g / m L$. Particle size of nanoparticles used, A and C $(4.8 \pm 1.6 \mathrm{~nm}) ; B$ and D $(7.8 \pm 2.3 \mathrm{~nm})$. CuO nanoparticles size $4.8 \pm 1.6 \mathrm{~nm}$ are used for determining MIC and MBC of Escherichia coli and Staphylococcus aureus.

Abbreviations: $\mathrm{CuO}$, copper oxide; ZOI, zone of inhibition; MIC, minimum inhibitory concentration; MBC, minimum bactericidal concentration; GK, gum karaya; TC, tetracycline.

of the Gram classes of bacteria. The antibacterial activity of $\mathrm{CuO}$ towards Gram-negative bacteria was higher when compared to Gram-positive bacteria. The difference in activity against these two types of bacteria could be attributed to the structural and compositional differences of the cell membrane. ${ }^{39}$ Gram-positive bacteria have thicker peptidoglycan cell membranes compared to the Gram-negative bacteria and it is harder for $\mathrm{CuO}$ to penetrate it, resulting in a low antibacterial response. ${ }^{40}$ Perelshtein et $\mathrm{al}^{5}$ reported that in the case of the CuO-coated fabric, the antibacterial effect was detected due to the $\mathrm{CuO}$ nanoparticles, which can generate reactive oxygen species that are responsible for damaging the bacteria's cells. In this context, a number of mechanisms have been proposed to interpret the antibacterial behavior of metal oxides. ${ }^{41}$

The differential sensitivity of bacteria towards $\mathrm{CuO}$ nanoparticles depends upon particle size, temperature of synthesis, bacterial cell wall structure, and the degree of contact with organisms with nanoparticles..$^{42}$ In our present investigation, the temperature of synthesis of $\mathrm{CuO}$ was maintained at $75^{\circ} \mathrm{C}$, and the particle size of the nanoparticle was found to be in the range of $2-10 \mathrm{~nm}$ sizes when using various concentrations of metal of precursor $(1 \mathrm{mM}, 2 \mathrm{mM}$, and $3 \mathrm{mM})$. Recently, Moloto et $\mathrm{a} \mathrm{l}^{43}$ have demonstrated that with an increase in precursor concentration, there was an increase in particle size, and the morphology evolved from spherical
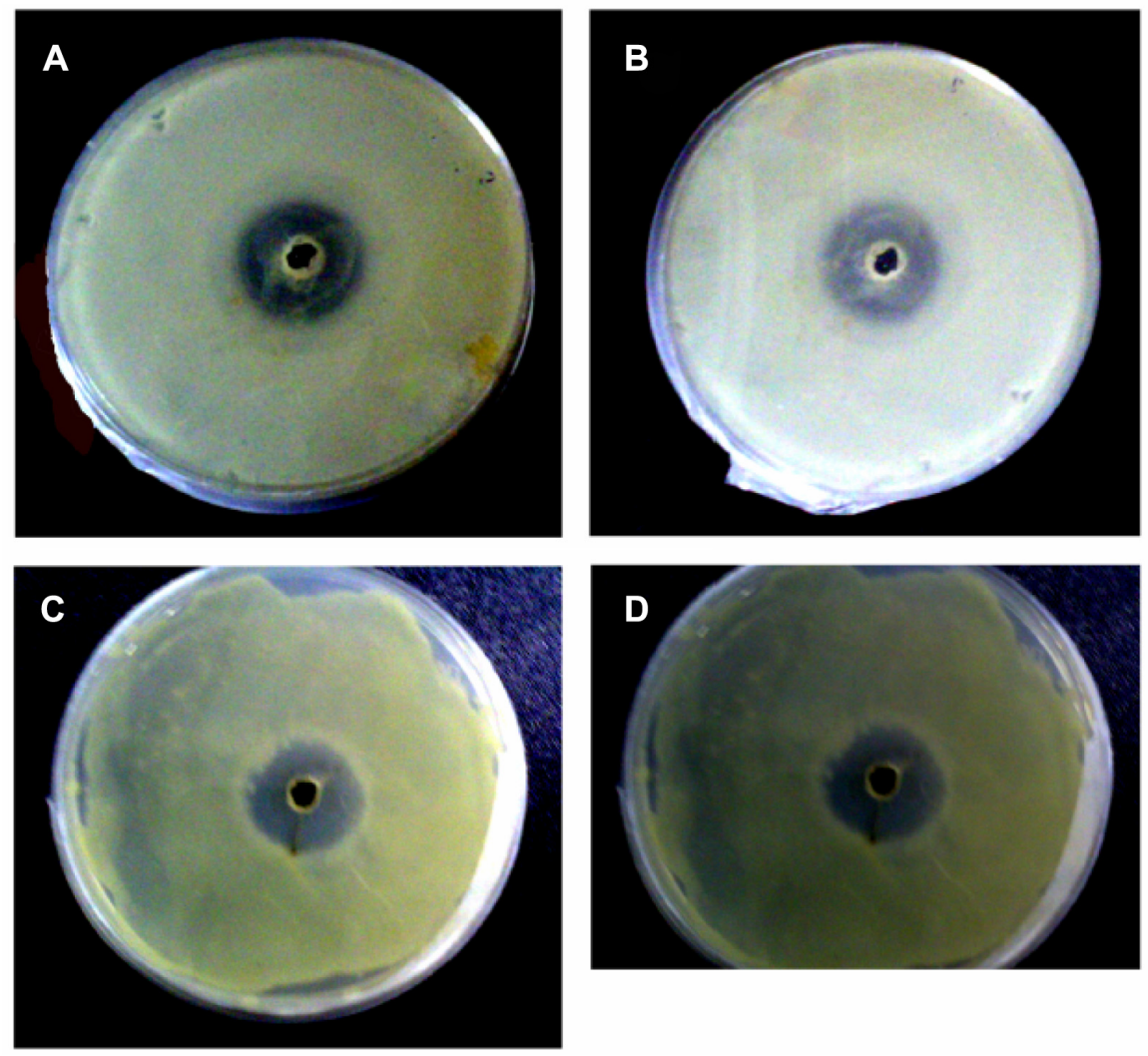

Figure 6 Bacterial cultures showing the inhibition zones around wells loaded with $50 \mu \mathrm{g}$ of CuO nanoparticles and (A) Escherichia Coli (MTCC 443$)$ representing inhibition zone formed with $4.8 \pm 1.6 \mathrm{~nm}$ size of $\mathrm{CuO}$ nanoparticles, (B) Escherichia Coli (MTCC 443) representing inhibition zone formed with $7.8 \pm 2.3 \mathrm{~nm}$ size of CuO nanoparticles, (C) Staphylococcus aurous (MTCC 737) representing inhibition zone formed with $4.8 \pm 1.6 \mathrm{~nm}$ size of CuO nanoparticles, and (D) Staphylococcus aurous (MTCC 737) representing inhibition zone formed with $7.8 \pm 2.3 \mathrm{~nm}$ size of $\mathrm{CuO}$ nanoparticles. Abbreviations: CuO, copper oxide; MTCC, Microbial Type Culture Collection. 
to rod-shaped cadmium sulfide nanoparticles, while others factors such as temperature and the capping group affected the growth of nanoparticles either in size and/or shape. The result of the present study is in agreement with their work. Further, the greater sensitivity of both Gram-positive and negative bacteria like $E$. coli and $S$. aureus to the $\mathrm{CuO}$ nanoparticles has been attributed to the greater abundance of amines and carboxyl groups on their cell surface and in the GK polymer template, which enhances the affinity of $\mathrm{Cu}$ ions towards these groups. ${ }^{26,44}$ Azam et $\mathrm{al}^{45}$ reported that smaller nanoparticle sizes and $\mathrm{CuO}$ nanoparticles synthesized in lower temperatures nanoparticles had higher antimicrobial behavior, which is in agreement with our present study. It is reported that the synthesis of $\mathrm{CuO}$ nanoparticles at various temperatures affects the antibacterial property of the nanoparticles; at high temperatures, ranging from $400^{\circ} \mathrm{C}-700^{\circ} \mathrm{C}$, the antibacterial property of both Gram-positive and negative bacteria, as well as the ZOI of the bacteria was found to be reduced. ${ }^{45}$ In the present investigation, a higher inhibition zone was observed for the Gram-positive S. aureus compared to other Gram-negative strains employed in this antibacterial susceptibility assay. ${ }^{46}$ The results of the present investigation also demonstrate that the excellent antibacterial behavior depends on the sizes of the synthesized $\mathrm{CuO}$.

\section{Conclusion}

The present green method for the synthesis of $\mathrm{CuO}$ nanoparticles is simple, mild, and environmentally friendly. The abundance of hydroxyl and carboxylate groups facilitates the formation of $\mathrm{Cu}(\mathrm{OH})_{2}$, which hydrolyzed later into nanocrystalline $\mathrm{CuO}$. The XRD pattern of GK is amorphous in nature, whereas the $\mathrm{CuO}$ is identical to that of pure $\mathrm{CuO}$, indicating the formation of single-phase $\mathrm{CuO}$ with a monoclinic structure. The average particle diameter, as determined by TEM, was found to be varied from $7.8 \pm 2.3 \mathrm{~nm}$ to $4.8 \pm 1.6 \mathrm{~nm}$ with respect to the concentration of the metal precursor used for the nanoparticles synthesis. FTIR, XRD, and XPS results corroborated the parity of synthesized $\mathrm{CuO}$ nanoparticles. The formed $\mathrm{CuO}$ nanoparticles are highly stable and have significant antibacterial action on both of the Gram classes of bacteria. The antibacterial activity experiment performed on $E$. coli and $S$. aureus clearly demonstrated that the smaller particle sizes of synthesized $\mathrm{CuO}$ nanoparticles have higher antibacterial effects and higher ZOI. This green method of synthesizing $\mathrm{CuO}$ nanoparticles could also be extended to fabricate other, industrially important metal oxides. The antibacterial activity of synthesized $\mathrm{CuO}$ nanoparticles using natural hydrocolloid GK is a promising contender for various applications in wound dressing, bed lining, active cotton bandages, as well as for medical and food applications.

\section{Acknowledgments}

The research reported in this paper was supported in part by the Project OP VaVpI Center for Nanomaterials, Advanced Technologies and Innovation CZ.1.05/2.1.00/01.0005, and by the Development of Research Teams of Research and Development Projects at the Technical University of Liberec CZ.1.07/2.3.00/30.0024.

\section{Disclosure}

The authors declare no conflicts of interest in this work.

\section{References}

1. Premkumar T, Geckeler KE. Nanosized CuO particles via a supramolecular strategy. Small. 2006;2(5):616-620.

2. Ren G, Hu D, Cheng EW, Vargas-Reus, MA, Reip P, Allaker RP. Characterisation of copper oxide nanoparticles for antimicrobial applications. Int J Antimicrob Agents. 2009;33(6):587-590.

3. Hsieh CT, Chen JM, Lin HH, Shih HC. Synthesis of well-ordered $\mathrm{CuO}$ nanofibers by a self-catalytic growth mechanism. Appl Phys Lett. 2003;82(19):3316-3318.

4. Zhang X, Wang G, Liu X, et al. Different $\mathrm{CuO}$ nanostructures: synthesis, characterization, and applications for glucose sensors. J Phys Chem C Nanomater Interfaces. 2008;112(43):16845-16849.

5. Perelshtein I, Applerot G, Perkas N, et al. CuO-cotton nanocomposite: formation, morphology, and antibacterial activity. Surface and Coatings Technology. 2009;204(1-2):54-57.

6. Lee HJ, Lee G, Jang NR, Yun JH, Song JY, Kim BS. Biological synthesis of copper nanoparticles using plant extract. Nanotechnology. 2011;1(1):371-374.

7. Valodkar M, Jadeja RN, Thounaojam MC, Devkar RV, Thakore S Biocompatible synthesis of peptide capped copper nanoparticles and their biological effect on tumor cells. Mater Chem Phys. 2011;128(1-2):83-89.

8. Akhavan $\mathrm{O}$, Ghaderi E. $\mathrm{Cu}$ and $\mathrm{CuO}$ nanoparticles immobilized by silica thin films as antibacterial materials and photocatalysts. Surface and Coatings Technology. 2012;205(1):219-223.

9. Hassan MS, Amna T, Yang OB, E1-Newehy MH, Al-Deyab SS, Khil MS Smart copper oxide nanocrystals: synthesis, characterization, electrochemical and potent antibacterial activity. Colloids Surf B: Biointerfaces. 2012;97:201-206.

10. Stoimenov PK, Klinger RL, Marchin RL, Klabunde KJ. Metal oxide nanoparticles as bactericidal agents. Langmuir. 2002;18(17): 6679-6686.

11. Kattumuri V, Katti K, Bhaskaran K, et al. Gum arabic as a phytochemical construct for the stabilization of gold nanoparticles: in vivo pharmacokinetics and X-ray-contrast-imaging studies. Small. 2007;3(2): 333-341.

12. Carnes CL, Klabunde KJ. The catalytic methanol synthesis over nanoparticle metal oxide catalysts. J Mol Catal A Chem. 2003;194(1-2): 227-236.

13. Zhu J, Li D, Chen H, Yang X, Lu L, Wang X. High dispersed CuO nanoparticles prepared by a novel quick-precipitation method. Mater Lett. 2004;58(26):3324-3327.

14. Kumar RV, Elgamiel R, Diamant Y, Gedanken A, Norwig J. Sonochemical preparation and characterization of nanocrystalline copper oxide embedded in poly(vinyl alcohol)and its effect on crystal growth of copper oxide. Langmuir. 2001;17(5):1406-1410.

15. Xu JF, Ji W, Shen ZX, et al. Preparation and characterization of $\mathrm{CuO}$ nanocrystals. J Solid State Chem. 1999;147(2):516-519. 
16. Hong ZS, Cao Y, Deng J. A convenient alcohothermal approach for low temperature synthesis of $\mathrm{CuO}$ nanoparticles. Mater Lett. 2002; 52(1-2):34-38.

17. Ahmad T, Chopra R, Ramanujachary KV, Lofland SE, Ganguli AK. Canted antiferromagnetism in copper oxide nanoparticles synthesized by the reverse-micellar route. Solid State Sciences. 2005;7(7) 891-895.

18. Wang H, Xu JZ, Zhu JJ, Chen HY. Preparation of $\mathrm{CuO}$ nanoparticles by microwave irradiation. J Cryst Growth. 2002;244(1):88-94.

19. Sun L, Zhang Z, Wang Z, Wu Z, Dang H. Synthesis and characterization of $\mathrm{CuO}$ nanoparticles from liquid ammonia. Mater Res Bull. 2005;40(6): 1024-1027.

20. Saravanan P, Alam S, Mathur GN. A liquid-liquid interface technique to form films of $\mathrm{CuO}$ nanowhiskers. Thin Solid Films. 2005;491(1-2):168-172.

21. Iravani S. Green synthesis of metal nanoparticles using plants. Green Chemistry. 2011;13(10):2638-2650.

22. Raveendran P, Fu J, Wallen SL. Completely "green" synthesis and stabilization of metal nanoparticles. J Am Chem Soc. 2003;125(46): 13940-13941.

23. Rao CN, Kulkarni GU, Thomas PJ, Edwards PP. Size-dependent chemistry: properties of nanocrystals. Chemistry. 2002;8(1):28-35.

24. Rana V, Rai P, Tiwary AK, Singh RS, Kennedy JF, Knill CJ. Modified gums: approaches and applications in drug delivery. Carbohydr Polym. 2011;83(3):1031-1047.

25. Verbeken D, Dierckx S, Dewettinck K. Exudate gums: occurrence, production, and applications. Appl Microbiol Biotechnol. 2003;63(1): $10-21$.

26. Le Cerf D, Irinei F, Muller G. Solution properties of gum exudates from Sterculia urens (karaya gum). Carbohydr Polym. 1990;13(4): 375-386.

27. Brito ACF, Sierakowski MA, Reicher F, Feitosa JPA, De Paula RCM. Dynamic rheological study of Sterculia Striata and Karaya polysaccharide in aqueous solution. Food Hydrocoll. 2005;19(5):861-867.

28. Silva DA, Brito ACF, de Paula RCM, Feitosa JPA, Paula HCB. Effect of mono and divalent salts on gelation of native, $\mathrm{Na}$ and deacetylated Sterculia striata and Stericulia urens polysaccharide gels. Carbohydr Polym. 2003;54(2):229-236.

29. Aspinall GO, Khondo L, Williams BA. The hex-5-enose degradation: cleavage of glycosiduronic acid linkages in modified methylated Sterculia gums. Can J Chem. 1986;65(9):2069-2076.

30. FAO. Karaya Gum. Rome: Food and Agricultural Organization; 1992. Available from: http://www.fao.org/ag/agn/jecfa-additives/specs/Monograph1/Additive-244.pdf. Accessed January 1, 2013.

31. Huang J, Li Q, Sun D, et al. Biosynthesis of silver and gold nanoparticles by novel sundried Cinnamomum camphora leaf. Nanotechnology. 2007;18(10):105104.

32. Vinod VTP, Sashidhar RB. Bioremediation of industrial toxic metals with gum kondagogu (Cochlospermum gossypium): A natural carbohydrate biopolymer. Indian J biotechnol. 2011;10(1):113-120.
33. Wiegand I, Hilpert K, Hancock RE. Agar and broth dilution methods to determine the minimal inhibitory concentration (MIC) of antimicrobial substances. Nat Protoc. 2008;3(2):163-175.

34. Vaseem M, Umar A, Kim SH, Hahn YB. Low-temperature synthesis of flower-shaped $\mathrm{CuO}$ nanostructures by solution process: formation mechanism and structural properties. J Phys Chem C Nanomater Interfaces. 2008;112(15):5729-5735.

35. Das D, Nath BC, Phukon P, Dolui SK. Synthesis and evaluation of antioxidant and antibacterial behavior of $\mathrm{CuO}$ nanoparticles. Colloids Surf B Biointerfaces. 2013;101:430-433.

36. Karthik K, Victor Jaya N, Kanagaraj M, Arumugam S. Temperaturedependent magnetic anomalies of $\mathrm{CuO}$ nanoparticles. Solid State Commun. 2011;151(7):564-568.

37. Durando M, Morrish R, Musca AJ. Kinetics and mechanism for the reaction of hexafluoroacetylacetone with $\mathrm{CuO}$ in supercritical carbon dioxide. J Am Chem Soc. 2008;130(49):16659-16668.

38. Ren G, Hu D, Cheng EW, Vargas-Reus MA, Reip P, Allaker RP. Characterization of copper oxide nanoparticles for antibacterial applications. Int J Antimicrob Agents. 2009;33(6):587-590.

39. Heinlaan M, Ivask A, Blinova I, Dubourguier HC, Kakru A. Toxicity of nanosized and bulk $\mathrm{ZnO}, \mathrm{CuO}$ and $\mathrm{TiO} 2$ to bacteria Vibrio fischeri and crustaceans Daphnia magna and Thamnocephalus platyurus. Chemosphere. 2008;71(7):1308-1316.

40. Tawale JS, Dey K, Pasricha R, Sood KN, Srivastava AK. Synthesis and characterization of $\mathrm{ZnO}$ tetrapods for optical and antibacterial applications. Thin Solid Films. 2010;519(3):1244-1247.

41. Gajjar P, Pettee B, Britt DW, Huang W, Johnson WP, Anderson AJ. Antimicrobial activities of commercial nanoparticles against an environmental soil microbe, Pseudomonas putida KT2440. J Biol Eng. 2009;3:9

42. Liang X, Sun M, Li L, Qiao R, Chen K, Xiao Q, Xu F. Preparation and antibacterial activities of polyaniline $/ \mathrm{Cu}_{0.05} \mathrm{Zn}_{0.95} \mathrm{O}$ nanocomposites, Dalton Trans. 2012;41(9):2804-2811.

43. Moloto N, Revaprasadu N, Musetha, PL, Moloto MJ. The effect of precursor concentration, temperature and capping group on the morphology of CdS nanoparticles. J Nanosci Nanotechnol. 2009;9(8): 4760-4766.

44. Beveridge TJ, Murray RG. Sites of metal deposition in the cell wall of Bacillus subtilis. J Bacteriol. 1980;141(2):876-887.

45. Azam A, Ahmed AS, Oves M, Khan MS, Memic A. Size-dependent antimicrobial properties of $\mathrm{CuO}$ nanoparticles against Gram-positive and -negative bacterial strains. Int J Nanomedicine. 2012;7(9): $3527-3535$

46. Son DI, You CH, Kim TW. Structural, optical, and electronic properties of colloidal $\mathrm{CuO}$ nanoparticles formed by using a colloid-thermal synthesis process. Appl Surf Sci. 2009;255(21):8794-8797.
International Journal of Nanomedicine

\section{Publish your work in this journal}

The International Journal of Nanomedicine is an international, peerreviewed journal focusing on the application of nanotechnology in diagnostics, therapeutics, and drug delivery systems throughout the biomedical field. This journal is indexed on PubMed Central, MedLine, CAS, SciSearch $\AA$, Current Contents ${ }^{\circledR} /$ Clinical Medicine,

\section{Dovepress}

Journal Citation Reports/Science Edition, EMBase, Scopus and the Elsevier Bibliographic databases. The manuscript management system is completely online and includes a very quick and fair peer-review system, which is all easy to use. Visit http://www.dovepress.com/ testimonials.php to read real quotes from published authors. 